\title{
Call for a bigger vision
}

\author{
Science in Canada cannot realize its full potential without clear direction from government.
}

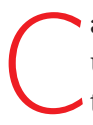
anada is in many ways a powerhouse of academic science: its university researchers are prolific publishers and strong contributors to the national research and development enterprise. Yet Canadian government policy does far too little to support and utilize this strength.

As described on page 159 of this issue, for example, the lack of a polar policy means that Canadian scientists working in the Arctic often find themselves with government grants to do research, but no funds for the helicopters and sea-planes needed to get people and gear to field sites. Scientists' calls for more coordinated funding through a national polar policy have been falling on deaf ears for decades, in governments dominated by both centre-left liberals and right-wing conservatives. A similar lack of action has greeted Canadian scientists' calls for a decision on replacing the ageing nuclear reactor at Chalk River in Ontario, which is not only their primary site for nuclear research, but is also relied on for much of the world's supplies of medical isotopes. The most recent national budget distributed a reduced portion of money in ways that dismayed the science community not least because it provided no funds for Genome Canada, an internationally competitive genomics and proteomics programme.

More generally, Canada has no group comparable to the American Association for the Advancement of Science in the United States for focusing attention on science policy. Lobbying of the government bodies that have power over science is fragmented. And Canada has nothing comparable to the White House Office of Science and Technology Policy, which is headed by a science adviser who reports directly to the US president. Canada did have a science adviser to the prime minister during 2004-08, but he was largely sidelined before the position was terminated. (There is currently only a 'minister of state' for science and technology, a junior post that lies within the industry ministry.) The council that replaced the science adviser is entirely reactive to government queries, and produces reports that traditionally are not made public.

One reason for this apparent neglect of science may be that Canada is so big and its population so small. Bodies that help to inform

the government about science, such as the Council of Canadian Academies, have neither the membership of their US equivalents nor the historical clout of those in Britain. Another reason may be that so much of Canada's wealth comes from natural resources, including timber and the oil sands, rather than from technical innovation. Perhaps this leads the government to see scientists as just another interest group, rather than as crucial contributors to the economy.

Whatever the reasons, Canada is failing to make the most of a key national resource. Everyone involved needs to take responsibility. The government should designate a single person to be

"The government should designate a single person to be held accountable for science." held accountable for science - either a chief adviser or a fully fledged minister with sufficient power and initiative to set a strong national agenda. Researchers, meanwhile, should find more effective ways of working together and making their voices heard, including becoming part of the political system themselves.

There are some hopeful signs. The very first Canadian Science Policy Conference was held in October 2009, attracting hundreds of participants. Its organizer, Mehrdad Hariri, a postdoctoral fellow at Toronto's McLaughlin-Rotman Centre for Global Health, hopes to build on that interest to create a formal network and centre for science policy. Meanwhile, the Ottawa-based Partnership Group for Science and Engineering, a body of some 50,000 individuals from industry, government and academia, has advocated the creation of 'science pages', a programme that would distribute timely, independent and open information on crucial science issues, and provide internships for Canadian scientists to obtain experience in the world of politics. Such ideas are well worth pursuing. But so far they are only proposals, without funding.

Some critics say Canada has no science policy at all. Others say it has unwritten laws that seem to let it muddle along. But muddling along isn't good enough in today's tough economic climate. Canada needs a bigger vision of where its science is going: a vision informed by organized scientists, and voiced by a strong position in government.

\section{Lessons from a pandemic}

\section{It is time to assess what worked, and what didn't, in the global efforts to cope with swine flu.}

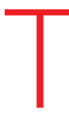

he world's response to the H1N1 flu pandemic over the past ten months suggests that the lessons learned from dealing with severe acute respiratory syndrome (SARS) and the threat of H5N1 avian flu have paid off. Researchers worldwide freely shared and published data covering the genetics, virology and epidemiology of the H1N1 virus in almost real time. Most national and international health agencies reacted swiftly and generally communicated openly with the media and the public. But the response also revealed serious weaknesses. The sobering fact is that humans were lucky with this pandemic. Most cases have been mild, yet health services were still often stretched to capacity. And the fact that vaccines were too few, too late, would have been catastrophic if the virus had been more lethal.

Health authorities in Mexico deserve credit for promptly alerting the world to the first outbreaks and acting to slow the spread of the disease, despite clear economic impacts from lost tourism and closed businesses. The transparency of the US Centers for Disease Control and Prevention (CDC) in Atlanta, Georgia, also deserves recognition. The agency's open sharing of data helped set the tone of the 